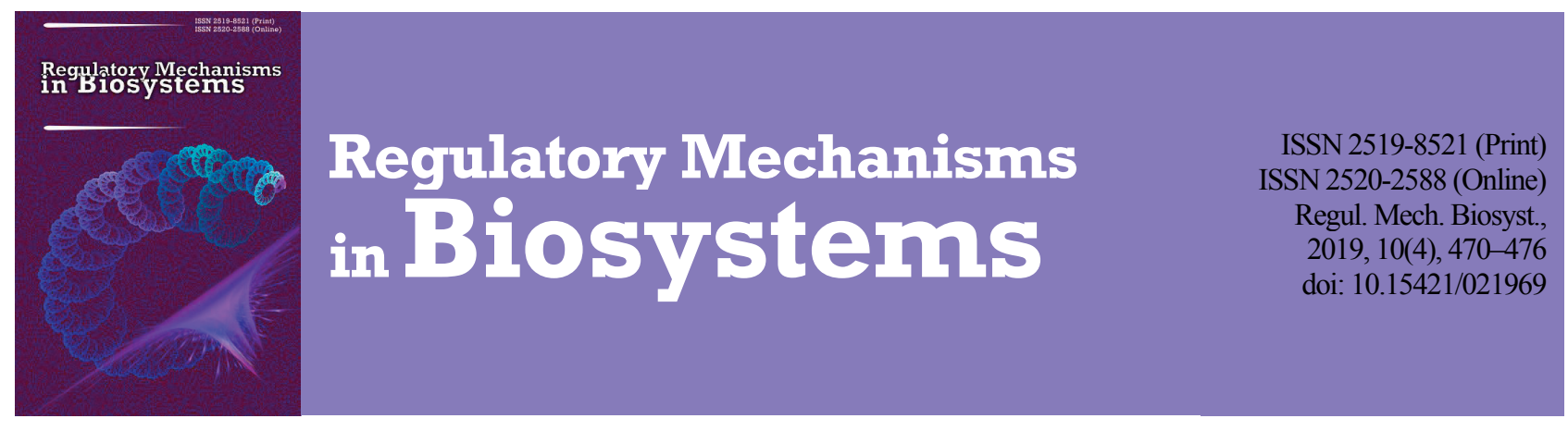

\title{
Features of Dictamnus albus (Rutaceae) in the pregenerative period of ontogeny in M. M. Gryshko National Botanical Garden in Ukraine
}

\author{
A. M. Gnatiuk
}

\author{
M. M. Gryshko National Botanical Garden of National Academy of Science of Ukraine, Kyiv, Ukraine
}

Article info

Received 24.03.2019 Received in revised form 20.04.2019 Accepted 23.04.2019

M. M. Gryshko National Botanical Garden of National Academy of Science of Ukraine, Timiryazevska st., 1 , Kyiv, 01014, Ukraine. E-mail:colchicum@i.ua

Gnatiuk, A. M. (2019). Features of Dictamnus albus (Rutaceae) in the pregenerative period of ontogeny in M. M. Gryshko National Botanical Garden in Ukraine. Regulatory Mechanisms in Biosystems, 10(4), 470-476. doi:10.15421/021969

Investigation of plant ontogenetic peculiarities and establishment of boundaries of ontogenetic states of individuals is a necessary basis for studying their populations. The minimal amount of data on morphology of plants in the pregenerative period of ontogenesis complicates plant identification in natural and cultural populations. Such information is especially important for rare species of plants. Dictamnus albus L. is a perennial rare plant listed in the Red Book of Ukraine. The objective of this research is to analyze the peculiarities of ontomorphogenesis of D. albus, to establish diagnostic signs of age stages and the sequence of their passage for identification of the multivariance of development. The results of the study on $D$. albus ontomorphogeny in the latent and pregenerative period at the M. M. Gryshko National Botanical Garden of the National Academy of Sciences of Ukraine are represented in this article. Diagnostic features of age stages: seeds, seedlings, juvenile, immature, virginile are established. The study shows a multivariate development that reveals different sequences of passing ontogenesis states by individuals and, accordingly, the rate of their aging and life expectancy. To describe the variation of the passage by individuals of ontogeny stages, we divided the stages into ontomorphs, which determined the degree of development-degradation of plants. The research showed that every age stage lasts for one growing season or longer. The first bloom in plants does not come earlier than the sixth year of vegetation. Seedlings and juvenile plants vary in leaf number and phyllotaxy. The development of immature plants takes place from the third year of vegetation. Seedlings, juvenile and young immature plants have a tap-root system. In individuals older than 4 years a root system forms which becomes similar to the fibrous root system due to the presence of several thickened roots. In immature and virginile plants, we observed the formation of adventitious roots on the caudex. It has been found that $D$. albus is characterized by heterophylly and morphological variability of leaves, which is developed during ontogeny and shoot formation. The variety of the architecture of individuals in the early stages of ontogenesis and the multi-variation of their development indicate the variation of the reaction rate.The data may be used for evaluate age (ontogenetic) structure of D. albus populations.

Keywords: development; ontogenesis; morphogenesis; rare plant; age stages; morphology; population structure.

\section{Introduction}

One in five of the world's plant species are at risk of extinction in the wild (Maschinski \& Albrecht, 2017; Pimm \& Raven, 2017). Botanic gardens fill an important niche in the plant conservation and research, primarily through the maintenance, development, and improvement of their living collections. This garden aspect of their mission essentially requires a long-term management plan and stability. The long-term commitment creates a fundamental biological understanding of the plants, their behaviour and life histories. Botanical gardens have a strong focus on the organism and the behaviour of the individual plant (Cannon \& Kua, 2017). This focus naturally leads to research on the populations and species of these plants ex situ.

Investigation of plant ontogenetic peculiarities and establishment of boundaries of ontogenetic states of individuals is a necessary basis for studying their populations. The minimal amount of data on morphology of plants in the pregenerative period of ontogenesis complicates plant identification in natural and cultural populations. Such information is especially important for rare species of plants. An assessment of the ontogenetic structure of the populations is necessary for forecasting the prospects for the development of the species in its phytocoenose and determining the strategy for its conservation (Chu \& Adler, 2013; Jolls et al., 2015; Baranovski et al., 2016; Khapugin et al., 2016; Kricsfalusy, 2016; Lykholat et al., 2017). Ontogenetic shifts in plants are ubiquitous, but their ecological and evolutionary significance remains largely unknown. Juveniles have few opportunities to accumulate sufficient biomass to withstand damage, whereas adults allocate resources for reproduction. Thus, age-specific environmental filters are expected to drive selection towards specific resource-investment strategies for each developmental stage. The juveniles exhibit greater intraspecific variability of strategies than adults, as a result of continuous filtering of traits throughout the plants' development towards adulthood (Dayrell et al., 2018).

The genus Dictamnus L. (Rutaceae) is represented in the flora of Ukraine by a two species: D. albus L. within the western (right-bank) part of the country (Podolsk Upland, Transcarpathia, North-Western Black Sea coast) and D. gymnostylis Stev. distributed within the eastern part of Ukraine and in Crimea (Dobrochaeva, 1955). European taxonomies tend to recognize only D. albus L. in the broadest sense (sensu lato), and distinguish from it a number of intraspecific taxa of different rank (Wolski \& Baj, 2014). The distribution area of $D$. albus covers the meridional and warm-temperate regions of Europe, Central, and Eastern Asia, where the populations are found along the fringes between xerothermic woodlands and (semi-) natural grasslands or within open oak forests. The species is locally protected across Europe and has been designated as 'vulnerable' in several European countries (Fisogni et al., 2016).

Dictammus albus L. (D. fraxinella DC.) or Burning Bush is a longlived perennial herb characterized by a pseudo-rhizome and thick storage roots. The individuals produce one to several stems that bear striking 
zygomorphic flowers in a long, pyramidal, loose spike. Stems are 40 $80 \mathrm{~cm}$ high, erect, woody at the base. Leaves alternate, odd- pinnate. Flowers bisexual, white to purple, often with prominent red streaks on the petals. Inflorescences terminal. Individual flowers have five petals (4 ascending and 1 descending). Sepals 5, basally connate. Stamens 10, distinct, declined, with prominent anthers. Gynoecium - 5-carpelled. All flower and fruit parts are covered by glandular trichomes. Ovaries basally connate, otherwise contiguous, style lateral, declined, of 5 basally coherent but apically connate stylar elements. Stigma punctiform. Fruit of 5 basally connate follicles; endocarp cartilaginous, discharged elastically with seeds at dehiscence (Dobrochaeva, 1955; Hensen \& Wesche, 2006). Seed with endosperm, weight of 1000 seeds is $17.8 \mathrm{~g}$ (Shanaida et al., 1998). Seeds are dispersed by increasing turgor pressure (autochory), which results in maximum dispersal distances of no more than $4 \mathrm{~m}$ (Frey, 2000). According to data of Mustafina et al. (2014), cutting of seed scars or scarification contributes to seed germination.

D. albus is listed in the Red Book of Ukraine as a rare plant (Diduch, 2009). D. albus is an attractive plant that has been cultivated for centuries. It is not only a decorative plant but possesses medicinal properties as well (Geneve et al., 1997; Beis et al., 2005; Martínez-Francés et al., 2015). Botanists have studied its morphological, biological and phytocoenotic features too (Jager et al., 1997; Partzsch, 2009).

According to the classification of life forms of plants (Serebryakov, 1962), D. albus relates to the summergreen, nonrosetteous category, with taproot system caudex-like-root-sarmentous, vegetative mobile, herbaceous polycarpic. It is a hemicryptophytic, erosulate forb non-rosette herbaceous plant with pleiocorm; deep reaching, with allo-homorhizic radication, thick storage roots, closed dormant buds, simple thyrsic or botrytis polyletic inflorescence panicle (compound raceme), low seed production (about 50 seeds per inflorescence) and subterranean germination (Jager et al., 1997). D. albus is a plant with a period of winter rest and a mid-summer period of flowering, which has a nonrosetteous model of structural organization. The main structural unit of the $D$. albus shoot system is a one-year erosulate monocyclic shoot, which develops from the underground resting bud that is wintering in the soil. All shoots are elongated: generative and vegetative. By Golubev's (1957) definition, the shoots of such plants have a two-phase development cycle: the bud and orthotropic leaf-covered shoot.

The literature contains data on the development of Dictammus in different parts of the range, its ontomorphogeny and the structure of populations (Jäger et al., 1997; Shanaida et al., 1998; Khodzhimatov, 2000; Varlamova, 2006; Partzsch, 2009; Mustafina et al., 2014). However, there is no unanimity in the description of size stage, age periods and age stages, which affects the adequate assessment of the conditions of its populations. Our observations on the development of plants in culture did not entirely coincide with the data given in the literature, which prompted us to generalize the data and to describe in detail the ontomorphogeny of D. albus in the M. M. Gryshko National Botanical Garden of the NAS of Ukraine.

The objective of the research is to analyze the peculiarities of ontomorphogenesis of D. albus, to establish diagnostic signs of age stages and the sequence of their passage for identification of the multivariance of development in D. albus. The data will be used to evaluate its age (ontogenetic) structure in Ukraine.

\section{Materials and methods}

The research was conducted in the M. M. Gryshko National Botanical Garden of the National Academy of Science of Ukraine (NBG). Observations were conducted over 7 years (2012-2018). The object of research consists of $D$. albus specimens grown from seeds. The seeds were collected from plants growing in the NBG collection and received from other institutions, in particular from Poland, Germany and Russia. To determine the degree of ontogenetic development of individuals, we use the terms "age-stage" and "age-period". The age stage of individuals was identified according to a set of structural characters of their overground and underground parts. We use the classification of age stages and the scheme of discrete description of ontogeny using the terminology of Rabotnov (1950) and Semenova (1989). The main criteria for identification of age periods and stages are following. Latent period $(s e)$ - dormant seeds. Pregenerative period: seedlings $(p)$ - have mixed nutrition (exist due to the substances of the seed and its own assimilation of the first leaves), there is a morphological connection with the seed, available embryonic structures: cotyledons, primary root and shoot. Juvenile stage ( $j$ ) is characterized by the simplicity of organization, the unsteadiness of signs and properties, which are not inherent in adult plants: the presence of another leaf form (juvenile leaves) and their phyllotaxy, another type of growth and branching, the retention of some embryonic structures (root, shoots); loss of connection with seeds; loss of cotyledons. Immature stage $(\mathrm{im})$ - properties and characteristics of plants are transitional from juvenile to adults: leaves and the root system are transitional (semi-adult) type, individual adult traits in the structure of the shoots are appearing (type of growth is changing, the branching begins), individual elements of the primary shoots are saved. Virginile stage $(v)$ - characterized by the appearance of the main features typical for the adult individuals. Plants have adult (definitivus) leaves, shoots and root system. Generative organs are still absent.

Ontomorphogeny was studied by conventional methods (Smirnova et al., 1976) of digging out and photographing of plants at different stages of development. Since $D$. albus is a rare species, the plants were replanted into the previous growth site after the research. Each age stage was described using at least 5-7 plants and the literature data (reference to add). The plant morphology was described in terms accepted in current ontogenetic studies (Artjushenko \& Fedorov, 1986; Mustafina et al., 2011).

The root system in D. albus is described by different authors as a rhizome (Dobrochaeva, 1955; Shanaida et al., 1998), a short rhizome (Diduch, 2009), a pseudo-rhizome with thickened stocking roots (Lavrenko, 1950), branched root of a taproot type (Mustafina et al., 2011). Serebryakov (1962) describes a short underground stem with renewal buds, similar to a vertical rhizome or caudex for $D$. albus. However, according to Fedorov et al. (1962) the term "stem-root" (caulorhiza) is more appropriate than "caudex". Jäger et al. (1997) call this formation a pleiocorm (pseudorhizome), since the main root is well expressed, dormant buds are located near the root collar and the plant is not able to divided into ramets. They point out that the whole root system corresponds to the term caulorrhiza. The complex structure of the underground part of the plant encouraged us to share the opinion of Oleynikova (2010), who suggests distinguishing plants with caulorrhiza as follows; those with annual underground shoots, those with perennial bases of monocarpic shoots and rootstocks. The term "caudex" is used to denote a perennial structural formation of stem nature, which occupies an intermediate position between the root and one-year above-ground stems, which is usually formed from the perennial basis of monocarpic shoots that remain after the death of their upper parts (Oleinikova, 2010) (Fig. 1).

The sizes of individuals in the text are given as an interval from the smallest to the largest values of the indicator (in brackets are given values that were rare). Separate conditions of morphogeny of individuals, which determined the degree of development-degradation of plants, were named as ontomorphotypes (ontomorphs), on the schemes they are denoted by digital indices. The sequence of plant development is shown schematically using the following characters: $\rightarrow-$ the transition to the next stage of development; | - completion of the vegetation; $\$-$ duration of more than one year. The goal was to determine the features of ontomorphogeny of plants in the NBG.

\section{Results}

The vegetation period of $D$. albus lasts about six months: it begins in the last decade of April - May, and ends in the first decade of October. In Kiev, the fruits ripen in July - August. Ontogeny of a plant starts from the latent period and the first age stage is seed (se). The next period of the plant's development is pregenerative (virginile), which consists of the following stages: seedlings $(p)$, juvenile $(j)$, immature $(\mathrm{im})$ and virginile $(v)$. We give detailed descriptions of plants in this periods and stages.

Latent period. Seed (se) - black, smooth, glossy, 3-4 mm long and 2.5-3.5 mm wide. Pear-shaped (obovoid or subglobose), apex rounded, base constricted with a white stripe of hilum extending up to the half of the seed. The suture (raphe) is barely visible, straight, rough, extends al- 
most to the base of the seed (Fig. 2a). Seed coat brittle, sclerenchymatous; endosperm copious; embryo straight; cotyledons broadly elliptic, flattened; hypocotyl partly included between cotyledons.

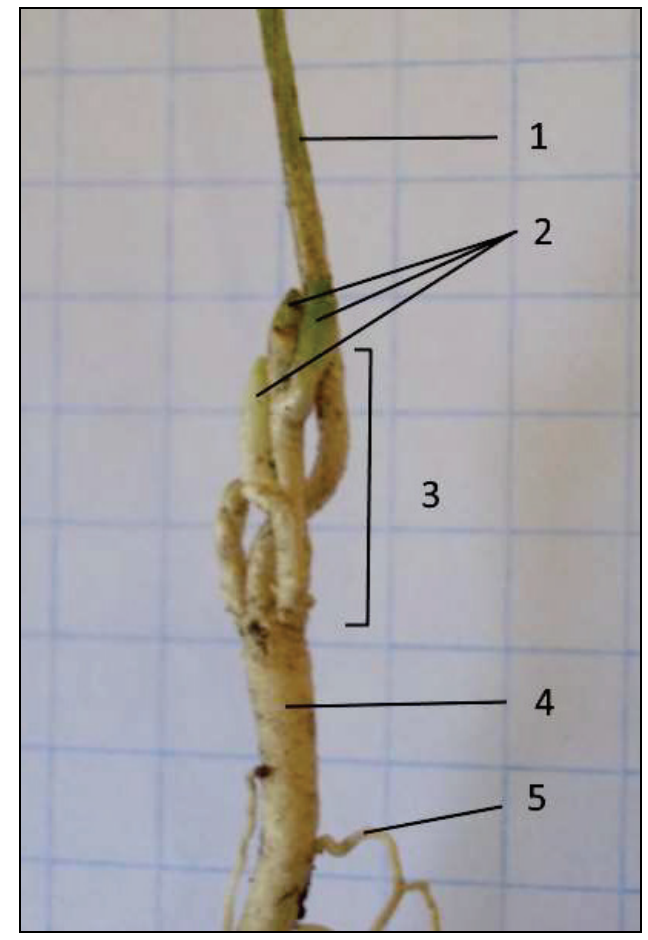

Fig. 1. A part of a two-year-old plant of Dictamnus albus L. in the end of vegetation: 1 - annual underground shoot, 2 - renewal (dormant) buds, 3 - caudex, 4 - primary root, 5 - lateral root

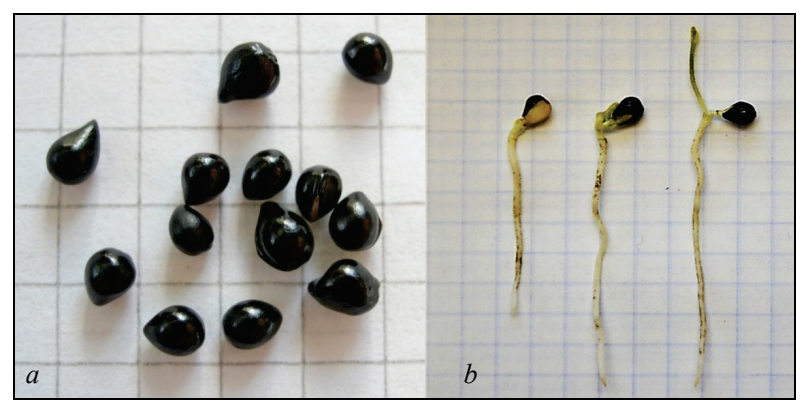

Fig. 2. Seeds of Dictamnus albus L. (scale cell $5 \times 5 \mathrm{~mm}$ ): $a$-dormant, $b$ - germinated

Pregenerative (virginile) period. In natural conditions, seedlings form in the spring. Sowing seeds in autumn or early winter gives good sprouting in the spring. If it is sown in early spring, the sprouts appear in the current year after 1.0-1.5 months after sowing. Under laboratory conditions, without stratification, only some of the seeds (about 10\%) sprout. At room temperature $\left(20-25^{\circ} \mathrm{C}\right)$ germination occurred on Day 18-20.

At first, the root (from the acute end of the seed) grows (Fig. 2b). Then, using the stocks of nutrients from the cotyledons remaining in the seed, a shoot with a leaf forms. After seed germination, there is a rapid growth of the root; the epicotyl is pulled out, trying to lift up the leaves to the surface of the soil as much as possible. Germination is underground (hypogeal), admotive, cotyledons remain underground in the seed coat. Subsequently, plants form 1-2 alternately true leaves of narrowelliptic $0.8-3.0 \mathrm{~cm}$ in length and up to $1 \mathrm{~cm}$ in width with a slightly wavy (sinuate) edge. Already at the stage of seedlings there is a difference in the formation of above-ground organs in different individuals. The first leaflets in some plants are placed alternately, others - opposite. By the end of June, the growth of individuals is complete. We should note that among seedlings there were plants without chlorophyll. Such plants were not capable of autotrophic feeding and died in the phase of 2-4 leaves, having exhausted their seed stocks (Fig. 3). Plants complete their development by the formation of shoots with 2-6 leaves, the ar472 rangement on the stem is different: opposite, alternate or verticillate. The taproot system with well-developed lateral roots and one renewal bud forms by the end of the vegetation. Thus, coeval individuals of the first year of vegetation (seedlings) are heterogeneous in the number of leaves and their placement on the shoots. The feature of one-year-olds is the presence of remnants of seeds (seed coat) and cotyledon leaves, which for a long time remain attached to the plants.

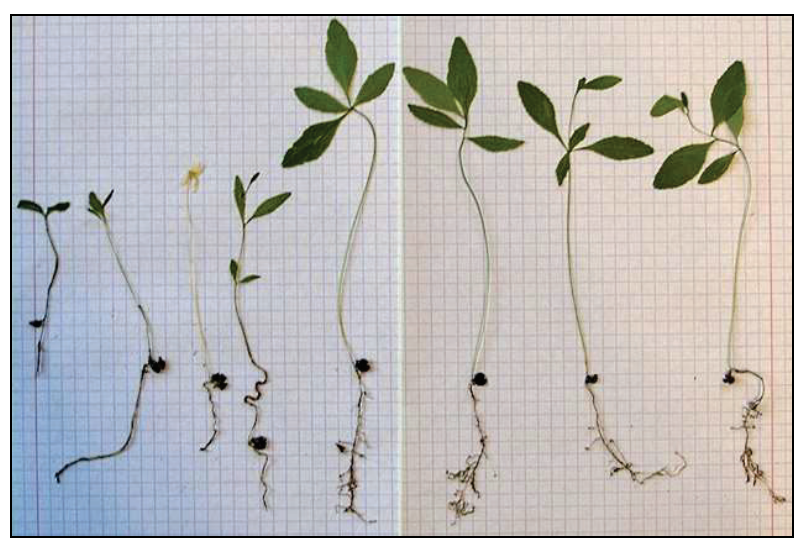

Fig. 3. One-year seedlings of Dictammus albus L. (grid scale $5 \times 5 \mathrm{~mm}$ )

Juvenile stage (j). In the second year of vegetation, plants that differ from seedlings by the presence of a pronounced major thickened root and lack of connection with the seed develop (Fig. 4). The monopodial type of growth of the shoots changes to sympodial.

Plants during the growing season form single orthotropic vegetative shoots with 4-11 leaves, which in shape, size and placement are similar to leaves of one-year old plants. Leaves 1-3 cm long, simple only, mostly short-petiolate, more rarely - sessile, arrangement on the stem alternately, oppositely or verticillate. The height of plants is 5-11 (12) cm. The root system is complicated, the main root in the lower part is branched, and the upper one-thickens. 1-3 (4) renewal buds formed at the base of the annual shoot.

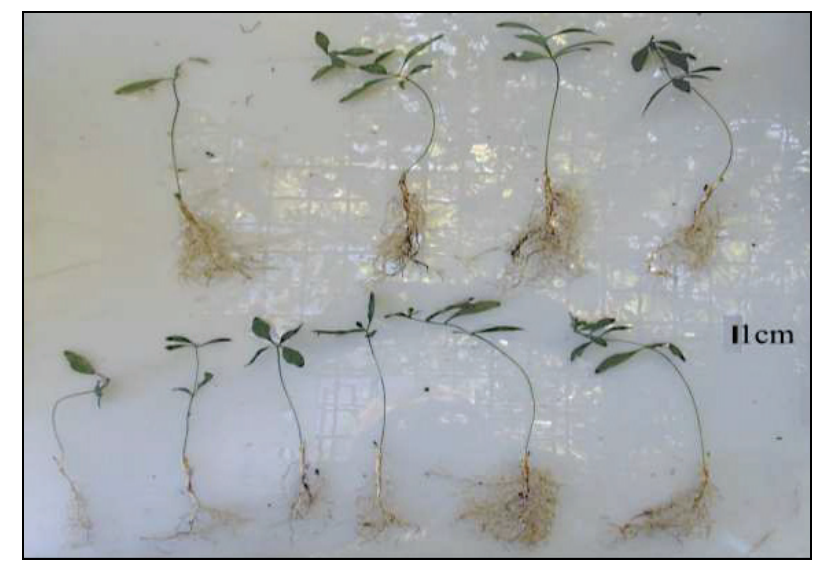

Fig. 4. Two-year-old juvenile plants of Dictamnus albus L.

Immature stage ( $\mathrm{im}$ ). The third year of vegetation in plants is characterized by a variety of individuals in habitus, which leads to further differentiation of their development. In the majority (in our experiment, there were $64 \%$ ) of three-year-old plants one shoot of $7-15 \mathrm{~cm}$ in height formed, with alternately placed 5-7 simple leaves and a well-developed central root with 1-2 buds on the caudex (Fig. 5). Leaves differ in shape and size from two-year leaves, they are larger and have a denticulate edge, lower leaves ( 1 or 2 ) sessile, and average - petiolate. Some individuals (15\%) formed plants with two shoots. Plants were 7-10 (15) cm tall with alternate 5-7 simple leaves on each shoot and a well developed root system with 1-4 renewal buds on the short caudex (diameter of the main root is about $0.5 \mathrm{~cm}$ ). Leaves 2.5 to $5.0(7.0) \mathrm{cm}$ in length and 2$5 \mathrm{~cm}$ in width are mostly elliptic or ovate. The leaves on the shoots are not the same in size: the first lower and last (upper) are smaller. The more developed three-year-old plants ( $21 \%$ of the studied ones) were

\footnotetext{
Regul. Mech. Biosyst., 2019, 10(4)
} 
15-20 cm high, characterized by the presence, besides simple, of pinnately compound leaves with 3-5 leaflets. Shoots have 5-7 (9) leaves and $1-5$ of them are compound. Individuals vary in degree of complexity and the number of pinnately compound leaves.

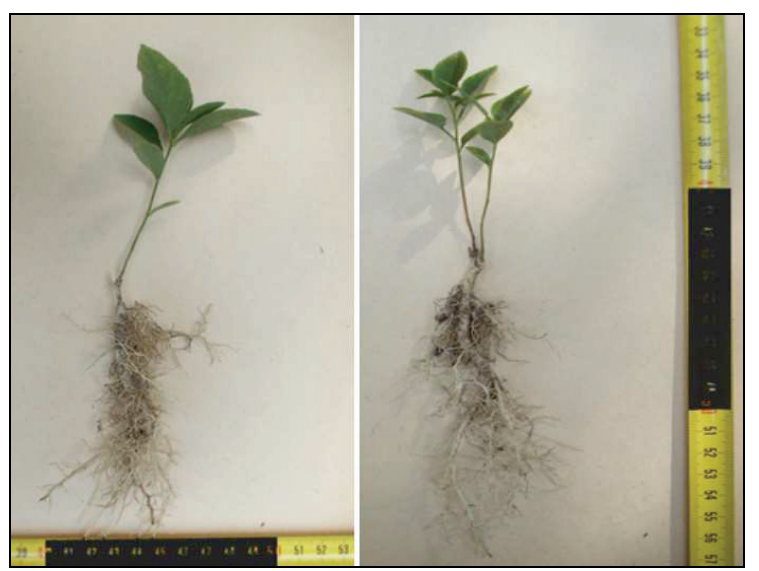

Fig. 5. Three-year-old immature plants of Dictamnus albus $\mathrm{L}$. with the simple leaves (dark zone on the scale $=10 \mathrm{~cm}$ )

During shoot development, at first, 1-2 (3) scale-like leaves (cataphylls) are formed, then 1-2 simple "true leaves" (euphylls) (the size of which increases in the direction of bottom-up), 1-2 medium compound leaves and the shoot ends with 1-2 simple leaves. In general, 6-8 true leaves on the plant are developing. Leaf placement obtains a certain order and becomes alternate.

Under optimal growth conditions, there is a "tillering" due to the development of several renewal buds. Otherwise, the plant develops only one shoot next year. During this period, the root system is developing as well and becomes branched with 3-5 thick roots and numerous lateral ones. Some parts of the caudex are rooted, which will give an opportunity for artificial vegetative propagation.

In general, immature plants are smaller than virginile in size, and have compound pinnate leaves mostly with 3-5 leaflets, often with incomplete separation of the terminal leaflet (Fig. 6). We consider it possible to divide this stage into two groups: young immature (with simple leaves) and adult immature (with compound leaves).

The further development of four-year and five-year plants is marked by increase in the size and branching of the overground and underground parts. It is worth noting that some researchers tend to refer all individuals with compound leaves to the virginile. We agree that the formation of compound leaves is a sign of "maturing" in individuals, though it does not fully reflect its sufficient development or the precondition for entry into the generative stage.

Virginile stage (v). The attainment by an individual of virginile stage occurs from the 5th year of life (Fig. 7) and is expressed in a greater similarity of its above-ground part to that in the generative individuals. There is heterophylly on the shoots. Plants form one or two aboveground shoots $25-35 \mathrm{~cm}$ high. Two-four (up to five) simple leaves at the low part are formed on the stem and they gradually die during the vegetation. Individuals form on a shoot 6-7 (8) pinnately compound leaves, predominantly odd-pinnate with 7-9 leaflets, often the top 1 or 2 leaves with 5-3 leaflets, size and branching type similar to those in generative individuals. Compound leaves $7.5-9.5 \mathrm{~cm}$ in length, the top leaf is 2.3 $2.5 \mathrm{~cm}$ in length and $1.5-1.8 \mathrm{~cm}$ in width, side leaves $2.5-2.2 \mathrm{~cm}$ in length and $1.0-1.3 \mathrm{~cm}$ wide. The root system has noticeable thick roots and a developed ramified partly rooted caudex.

\section{Discussion}

We know that plants exhibit phenotypical plasticity. Their general body plan is genetically determined, but plant architecture and branching patterns are variable and can be adjusted to the prevailing environmental conditions. The modular design of the plant facilitates such morphological adaptations. The prerequisite for the formation of a branch is the initiation of an axillary meristem. After its establishment, the meri- stem can be developed into a bud, which can either become dormant or grow out and form a branch. Many endogenous factors, such as photo assimilate availability, and exogenous factors like nutrient availability or shading, have to be integrated in the decision about whether a branch is formed (Teichmann \& Muhr, 2015).

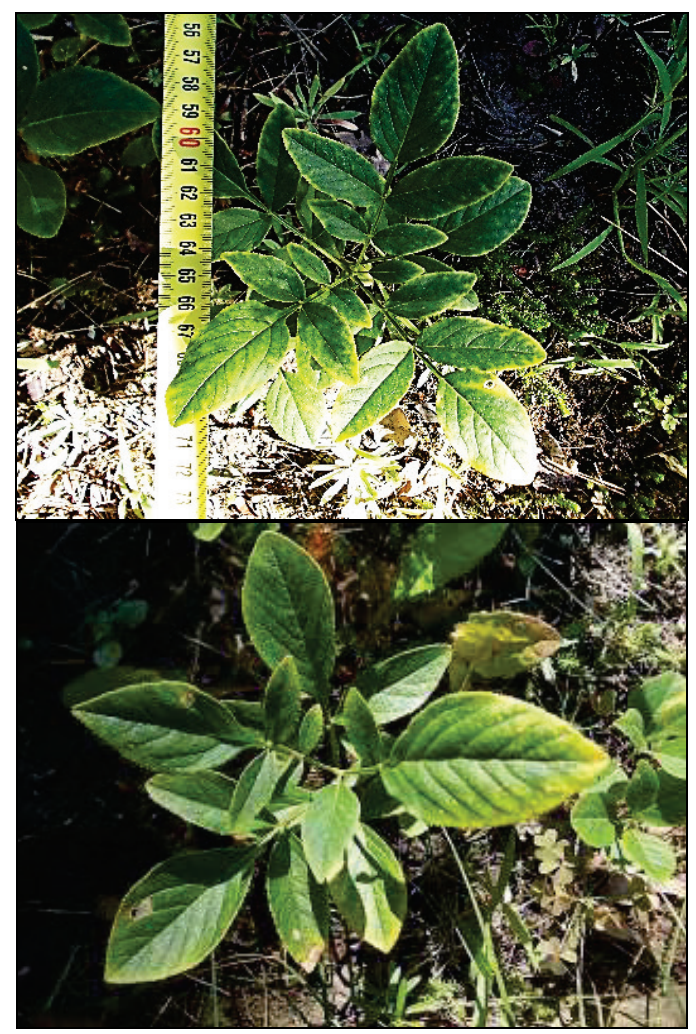

Fig. 6. Three-year-old immature plants of Dictamnus albus L. with the compound leaves (above-ground part)

We should note that our observations of Dictamnus growth and development do not entirely coincide with those given in the literature. For example, Mustafina et al. $(2011,2014)$ note that the seeds of the D. gymnostylis have an epigeal germination and sprouts form two cotyledon leaves (Gnatiuk, 2017). At the same time, other authors point out the hypogeal germination for Dictamnus (albus and tadzhikorum) (Shanaida et al., 1998; Khojimatov, 2000), which we also observed. Perhaps, in nature there are many seedlings with two opposing leaves. These plants are false-typed by researchers as sprouts with two cotyledon leaves. Khojimatov (2000) notes that one-year-old individuals of $D$. tadzhikorum have 1-2 pairs of opposite leaves. Our studies showed greater variability of seedlings by the number of leaves and their placement on the stem (Fig. 2). We want to note that Mustafina et al. $(2011,2014)$ for juvenile individuals describe only 4-6 sessile leaves of the juvenile type, while Khojimatov (2006) observes that the individuals of the D. tadzhikorum Vved. in the first year of development form opposite leaves and only in old individuals do leaves become alternate. This can be explained by the species-specific ontogeny under certain conditions, or misidentification of two-year juvenile individuals as seedlings, which relies mostly on the structure of their above-ground parts. We want to note, that Khodzhimatov $(2000,2006)$ writes that the D. tadshikorum of 6-7years develops only one shoot, which annually dies.

Shanaida et al. (1988) refers to juvenile all individuals with simple leaves and note that at the end of the juvenile stage, the main root stops its activity, and the root system is represented by the system of lateral roots and rhizome. According to their data, the juvenile stage lasts 34 years. Immature stage include 3-4-year-old specimens with compound leaves with 3-5 leaflets, and the virginile includes compound leaves with 9 leaflets on compound leaves and long rhizomes with additional roots. The authors note that virginile plants are able to achieve vegetative propagation (Shanaida et al., 1988). 


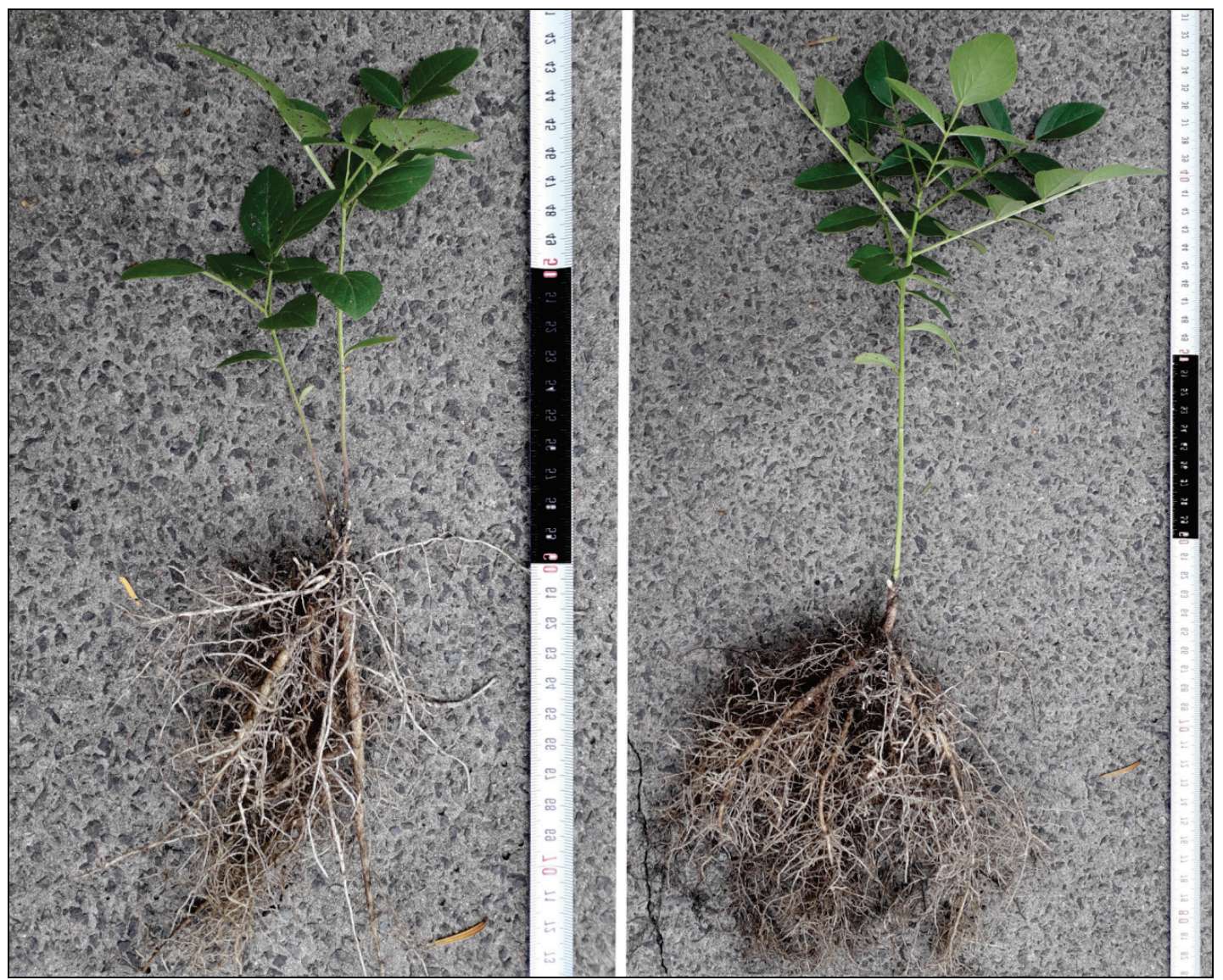

Fig. 7. Five-year-old plants of Dictamnus albus L.: $a$-immature plant, $b$ - virginile plant
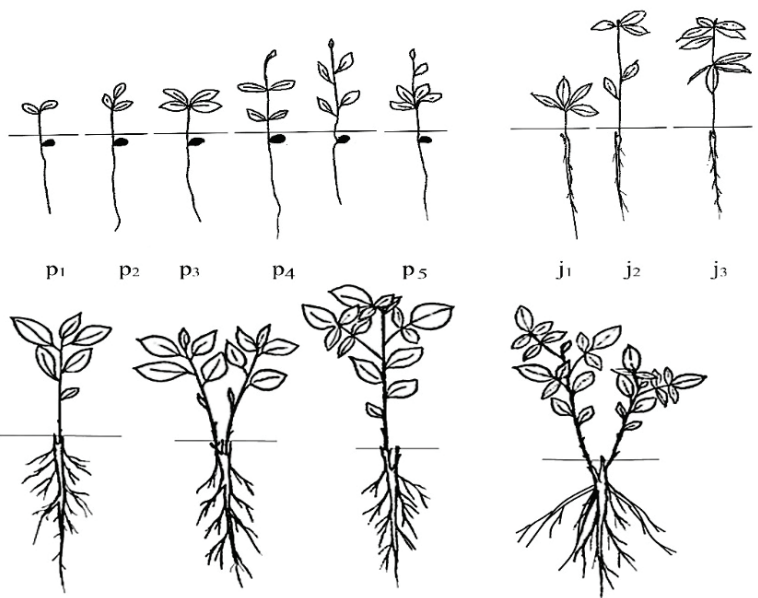

$\mathrm{p}_{4}$

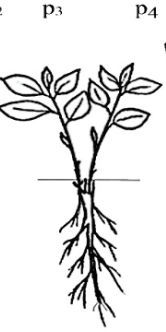

$\mathrm{p}_{5}$

imı

$\mathrm{im}_{2}$

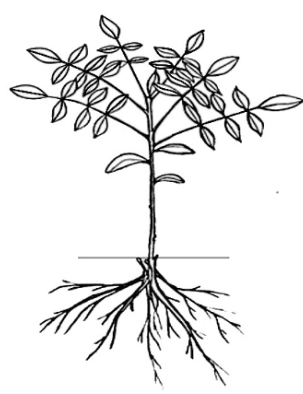

$\mathrm{V}_{1}$
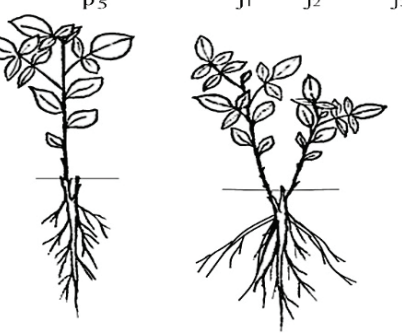

$\mathrm{im}_{4}$

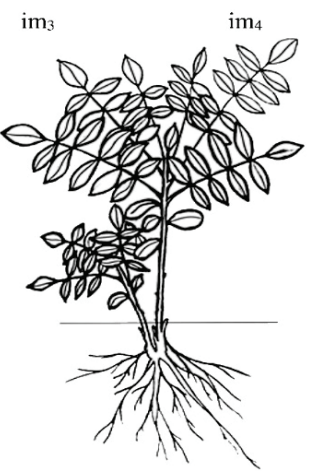

$\mathrm{V}_{2}$

Fig. 8. Scheme of Dictammus albus L. age stages: seedlings ( $p$ ), juvenile $(j)$, immature (im), virginile (v)
Partzsch (2009) was studied the demographic structure of D. albus of the lower Unstrut-valley (Saxony-Anhalt) by counting the number of seedlings, juvenile shoots lower and higher than $20 \mathrm{~cm}$, and adults based on the investigations by Jager et al. (1997). She described the following development stages: seedlings - plants with simple leaves (1-3 years), juvenile $<20 \mathrm{~cm}-4-5$-year plants with pinnate leaves, juvenile $>20 \mathrm{~cm}-6-7$-year plants with pinnate leaves, adult $-8-30$-years plants with flowers or fruits (Partzsch, 2009).

Our studies of $D$. albus ontogeny have shown that it is characterized by multivariate ways of development of some morphogenetic phases. In culture under conditions of NBG the pregenerative (virginile) period of $D$. albus ontogeny shows a multivariate type of development. The diversity of biomorphs (ontomorphotypes) in different age and agestages of ontogeny is depicted in Figure 8.

The order, duration and speed of their passing depend on the conditions of plant growth (nutrient supply, moisture, light during the vegetation period). The age stages of seedling and juvenile lasts for a one year, the immature and virginile stages may last for several years. The most morphologically differentiated was the stage of seedlings. They differed in the number of leaves (2-6) and their arrangement (opposite, alternate or verticillate). The immature stage for the degree of development of individuals (type of branching and the number of metameres) is divided into four ontomorphotypes: $\mathrm{im}_{1}-\mathrm{im}_{4}$, virginile stage - in two.

Under growth conditions of NBG, individuals developed in the following sequence (Gnatiuk, 2018):

1) $\mathrm{p}_{1}\left|\rightarrow \mathrm{j}_{1}\right| \rightarrow \mathrm{im}_{1}\left|\rightarrow \mathrm{im}_{2}\right| \rightarrow \mathrm{im}_{3}\left|\rightarrow \mathrm{im}_{4} \ddagger\right| \rightarrow \mathrm{v}_{2}$;

2) $\mathrm{p}_{1} \rightarrow \mathrm{p}_{2}\left|\rightarrow \mathrm{j}_{2}\right| \rightarrow \mathrm{im}_{2}\left|\rightarrow \mathrm{im}_{4}\right| \rightarrow \mathrm{v}_{2} \mid$;

3) $\mathrm{p}_{1} \rightarrow \mathrm{p}_{2} \rightarrow \mathrm{j}_{2} \rightarrow \mathrm{im}_{1} \rightarrow \mathrm{im}_{3} \rightarrow \mathrm{v}_{1} \rightarrow \mathrm{v}_{2}$

4) $\mathrm{p}_{1} \rightarrow \mathrm{p}_{4}\left(\mathrm{p}_{5}\right)\left|\rightarrow \mathrm{j}_{3}\right| \rightarrow \mathrm{im}_{2}\left|\rightarrow \mathrm{im}_{4}\right| \rightarrow \mathrm{v}_{1} \mid$

5) $\mathrm{p}_{1} \rightarrow \mathrm{p}_{4}\left(\mathrm{p}_{5}\right)\left|\rightarrow \mathrm{j}_{3}\right| \rightarrow \mathrm{im}_{2}\left|\rightarrow \mathrm{im}_{3}\right| \rightarrow \mathrm{v}_{1} \mid ;$
6) $\mathrm{p}_{1} \rightarrow \mathrm{p}_{5}\left|\rightarrow \mathrm{j}_{3}\right| \rightarrow \mathrm{im}_{2}\left|\rightarrow \mathrm{im}_{1}\right| \rightarrow \mathrm{im}_{3}\left|\rightarrow \mathrm{im}_{4}\right| \rightarrow \mathrm{v}_{1} \mid$.

We want to note that the effect of adverse environmental factors does not always slow down the development of individuals. In particular, under conditions of artificial drought, young immature plants during the early onset of the rest period (in June) of the same year, renewal of 
irrigation, the shoots are formed bearing compound leaves which are inherent in immature individuals of older age. Plants not exposed to such stress still formed only simple leaves the following season. The immature stage can take several years. The aboveground part of plants will display transitions both in forward and in the opposite direction $\left(\mathrm{im}_{1} \leftrightarrow \mathrm{im}_{2}\right.$ and $\mathrm{im}_{3} \leftrightarrow \mathrm{im}_{4}$ ), which does not mean rejuvenation of plants, but reflects the degree of development-degradation of individuals. Prolonged stay of plants in the immature stage will be the fastest indication of the inconsistency of optimum conditions of growth and will lead to a gradual transition to the subsenile stage due to elimination of the generative period of ontogenesis. Delay in development in the virginile stage is also most often due to the influence of external conditions.

\section{Conclusions}

Our research shows that, as a result of generative reproduction, D. albus forms a generation of individuals, which at the early stages of ontogenesis differed in their rates of development. Under growth conditions of NBG, we observed 6 variants of passing of the pregenerative period of ontogenesis by individuals. The pregenerative period of ontogenesis of $D$. albus plants includes 4 age stages, within which we have identified and described the following ontomorphotypes: 5 in the seedlings, 4 in the immature and 2 in the virginile stages. To the stage of seedlings, we assign 1-year-old plants that have evolved from that year's seeds. To juvenile plants, we assign only two-year-olds. To immature stage - individuals aged 3 years or more, which are very different from the juvenile and the virginile by the structure of the aboveground organs. We consider it is possible to divide this stage into two groups: young immature (with simple leaves) and adult immature (with complex leaves).

Under growth conditions of NBG, plants in the seedling, juvenile and young immature stages have a tap-root system. The individuals older than 4 years form a root system which becomes similar to a fibrous root system, since several thickened roots. In immature and virginile plants, we observed the formation of adventitious roots on the caudex. We found that $D$. albus is characterized by heterophylly and morphological variability of leaves, which is manifested during ontogeny and shoots formation.

The variability of the architecture of individuals in the early stages of ontogenesis and the multi-variation of their development indicates the variability of the reaction rate of the species and the "search" for the optimum biomorph for specific growth conditions. This explains the inconsistencies in the identification of age of individuals in different geographical and climatic regions. The polyvariance of the development of individuals grown from seeds also suggests phenotypic plasticity, which is genetically determined.

\section{References}

Artjushenko, Z. T., \& Fedorov, A. A. (1986). Atlas po opisatel'noj morfologi vysshih rastenij. Plod [Atlas on descriptive morphology of higher plants. Fruit]. Nauka, Leningrad (in Russian).

Baranovski, B., Khromykh, N., Karmyzova, L., Ivanko, I., \& Lykholat, Y. (2016) Anyalysis of the alien flora of Dnipropetrovsk province. Biological Bulletin of Bogdan Chmelnitskiy Melitopol State Pedagogical University, 6(3), 419-429.

Beis, R., Öztürk, Y., Aydin, S., \& Gürer, F. (2005). Pharmacological and toxicological effects of Gas plant (Dictammus albus L.). Turkish Journal of Pharmaceutical Sciences, 2(3), 111-124.

Cannon, C. H., \& Kua, C. (2017). Botanic gardens should lead the way to create a "Garden Earth" in the Anthropocene. Plant Diversity, 39(6), 331-337.

Chu, C., \& Adler, P. B. (2013). When should plant population models include age structure? Journal of Ecology, 102, 531-543.

Dayrell, R. L. C., Arruda, A. J., Pierce, S., Negreiros, D., Meyer, P. B., Lambers, H., \& Silveira, F. A. O. (2018). Ontogenetic shifts in plant ecological strategies. Functional Ecology, 32(12), 2730-2741.

Diduh, J. P. (Ed.). (2009). Chervona knyga Ukrayiny. Roslynnyj svit [Red Book of Ukraine. Plants]. Globalkonsaltyng, Kyiv (in Ukrainian).

Dobrochaeva, D. M. (1955). Rid 499. Dictammus. Flora URSR [Genus 499. Dictammus. Flora of USSR]. AN URSR, Kyiv. Vol. 7. Pp. $90-94$ (in Ukrainian).

Fedorov, A. A., Kirpichnikov, M. E., \& Artyushenko, Z. T. (1962). Atlas po opisatelnoy morfologii vyisshih rasteniy. Stebel i koren [Atlas of descriptive morphology of higher plants. Stem and root]. Nauka, Leningrad (in Russian).
Fisogni, A., Rossi, M., Sgolastra, F., Bortolotti, L., Bogo, G., de Manincor, N., Quaranta, M., \& Gallon, M. (2016). Seasonal and annual variations in the pollination efficiency of a pollinator community of Dictamnus albus L. Plant Biology, 18, 445-454.

Frey, W. (2000). Life strategies as a basis for functional characterization of plant species and plant communities: A case study. Zeitschrift fuer Oekologie und Naturschutz, 9, 35-41.

Geneve, R. L., Jones, R. O., \& Kester, S. T. (1997). Micropropagation of Dictamnus albus L. (gas plant). Biotechnology in Agriculture and Forestry. HighTech and Micropropagation VI. Springer-Verlag, Berlin Heidelberg.

Gnatiuk, A. M. (2017). Morfologichni osoblivosti Dictamnus albus L. na pochatkovih etapah ontomorfogenezu [Morphological features of Dictamnus albus L. in the early stages of ontomorphogenesis]. Materiali XIV z'yizdu Ukrayinskogo botanichnogo tovaristva. Kyiv. P. 178 (in Ukrainian).

Gnatiuk, A. M. (2018). Adaptyvni reaktsiyi deyakyh ridkisnyh vydiv roslyn na pochatkovyh etapah ontogenezu ex situ [Adaptive reactions of some rare plant species in the early stages of ontogeny ex situ]. Materialy mizhnarodnoyi naukovoyi konferentsiyi "Zberezhennya riznomanittya roslinnoho svitu u botsadah ta dendroparkah: Tradytsiyi, suchasnist, perspektyvy". BilaTserkva. Pp. 77-82 (in Ukrainian).

Golubev, V. N. (1957). O morfogeneze i evolyucii zhiznennyh form travyanistyh rastenij leso-lugovoj zony [On the morphogenesis and evolution of life forms of herbaceous plants of the forest-meadow zone]. Byuleten Moskovskogo Obshchestva Ispytateley Prirody, Otdelenie Biologii, 62(6), 35-57 (in Russian).

Hensen, I., \& Wesche, K. (2006). Relationships between population size, genetic diversity and fitness components in the rare plant Dictamnus albus in Central Germany. Biodiversity and Conservation, 15, 2249-2261.

Hodzhimatov, M. (2000). Yasenec tadzhikskij (Dictammus tadshikorum Vved.), ego biologicheskie osobennosti i vozmozhnost ispolzovaniya $\mathrm{v}$ narodnom hozyajstve [Tajik ash-tree (Dictamnus tadshikorum Vved.), its biological features and the possibility of use in the national economy]. Dushanbe (in Russian).

Hodzhimatov, M. (2006). Rost i izmenchivost Dictamnus tadshikorum Vved. v virginilnom periode [Growth and variability of Dictamnus tadshikorum Vved. in the virginile period]. Doklady Akademii Nauk Respubliki Tadzhikistan, 49(1), 73-77 (in Russian).

Jolls, C. L., Marik, J. E., Hamze, S. I., \& Havens, K. (2015). Population viability analysis and the effects of light availability and litter on populations of $\mathrm{Cir}$ sium pitcheri, a rare, monocarpic perennial of Great Lakes shorelines. Biological Conservation, 187, 82-90.

Jager, E. J., Johst, A., \& Lorenz, H. (1997). Wuchsform und Lebensgeschichte von Dictamnus albus L. (Rutaceae). Hercynia, 30, 217-226 (in German).

Khapugin, A. A., Silaeva, T. B., Semchuk, A. A., \& Kunaeva, E. N. (2016). Populations of Orchis militaris, Epipactis palustris and Malaxis monophyllos in the Republic of Mordovia (Central Russia). Biodiversity: Research and Conservation, 42(1), 33-40.

Kricsfalusy, V. (2016). Variations in the life cycle of Anemone patens L. (Ranunculaceae) in Wild Populations of Canada. Plants, 5, 29.

Lavrenko, E. M. (1950). Nabljudenija nad predzimnim sostojaniem i kornevoj sistemoj nekotorych rastenij jufnoj Kirgizii [Observations on the state of the pre-winter and root systems of certain plants of southern Kyrgyzstan]. Byuleten Moskovskogo Obshchestva Ispytateley Prirody, Otdelenie Biologii, 55(4), 51-62 (in Russian).

Lykholat, Y. V., Khromykh, N. A., Ivan'ko, I. A., Matyukha, V. L., Kravets, S. S., Didur, O. O., Alexeyeva, A. A., \& Shupranova, L. V. (2017). Assessment and prediction of the invasiveness of some alien plants under the climatic changes in the steppe Dnieper. Biosystems Diversity, 25(1), 52-59.

Martínez-Francés, V., Rivera, D., Heinrich, M., Obon, C., \& Ríos, S. (2015). An ethnopharmacological and historical analysis of "Dictamnus", a European traditional herbal medicine. Journal of Ethnopharmacology, 175(4), 390-406.

Maschinski, J., \& Albrecht, M. A. (2017). Center for Plant Conservation's Best Practice Guidelines for the reintroduction of rare plants. Plant Diversity, 39(6), 390-395.

Mustafina, A. N., Abramova, L. M., \& Shigapov, Z. H. (2014). Yasenec golostolbikovyj v Bashkortostane: Biologiya, struktura populyacij, introdukciya [Burning bush in Bashkortostan: Biology, population structure, introduction, protection]. Gilem, Ufa (in Russian).

Mustafina, A. N., Karimova, O. A., \& Andreeva, I. Z. (2011). Ontogenez yasenca golostolbikovogo (Dictammus gymnostylis Stev.) [Ontogenesis of burning bush (Dictamnus gymnostylis Stev.)]. In: Ontogeneticheskij atlas rastenij. JoshkarOla. Vol. 6. Pp. 94-97 (in Russian).

Oleynikova, E. M. (2010). Klassifikatsiya modeley strukturnoy organizatsii travyanistlh sterzhnekornevyih rasteniy voronezhskoy oblasti [Classification of models of structural organization of herbaceous rooted plants of the Voronezh region]. Vestnik Voronezhskogo Gosudarstvennogo Universiteta, Seriya Himiya, Biologiya, Farmatsiya, 1, 99-106 (in Russian).

Partzsch, M. (2009). Populationsstruktur und Vergesellschaftung von Dictamnus albus L. in thermophilen Säumen des unteren Unstruttals (Sachsen-Anhalt). Tuexenia, 29, 63-82. 
Pimm, S. L., \& Raven, P. H. (2017). The fate of the world's plants. Spotlight, 32(5), 317-320.

Rabotnov, T. A. (1950). Zhiznennyj cikl mnogoletnih travyanistyh rastenij v lugovyh cenozah [The life cycle of perennial herbaceous plants in meadow cenosis]. Trudy Botanicheskogo Instituta AN SSSR, Geobotanika, 6, 179-196 (in Russian).

Semenova, G. P. (1989). Introdukciya redkih rastenij kak metod uskorennogo izucheniya ontogeneza [Introduction of rare plants as a method of accelerated learning of ontogenesis]. In: Recommendations: Ontogeny of higher flowering plants. TSUOP Gosagroproma URSR, Kyiv. Pp. 117-122 (in Russian).

Serebryakov, I. G. (1962). Ekologicheskaya morfologiya rastenij i ih izuchenie [Ecological morphology of plants and their study]. Vysshaya shkola, Kyiv (in Russian)

Shanaida, N. D., Barna, M. M., Zelinka, S. V., Cherniak, V. M., \& Shanaida, M. I. (1998). Ontohenez ta vikova struktura populiatsii Dictamnus albus L. v umovakh Holytskoho botaniko-entomolohichnoho [Ontogenesis and age structure of the population of Dictamnus albus L. in the conditions of Golitsky Botanical and Entomological Reserve]. Naukovi Zapysky Ternopilskogo
Derzhavnogo Pedagogichnogo Universytetu Imeni Volodymyra Hnatiuka, Serija Biologichna, 2(4), 26-30 (in Ukrainian).

Smimova, O. V., Zaugolnova, L. B., Ermakova, I. M., Bogdanova, N. M., Grigorjeva, V. N., Yegorova, V. N., Zhukova, L. A., Matveev, A. P., Mihajlova, N. F., Sugorkina, N. S., Uranov, A. A., \& Cheburaeva, A. N. (1976). Cenopopuljacii rastenij (osnovnye ponjatija i struktura) [Cenopopulations of plants (basic concepts and structure)]. Nauka, Moscow (in Russian).

Teichmann, T., \& Muhr, M. (2015). Shaping plant architecture. Frontiers in Plant Science, 6, 233.

Varlamova, M. A. (2006). Dictamnus gymnostylis Stev. na Yuzhnom Urale: Sostoyanie prirodnyh populyacij i voprosy ohrany [Dictamnus gymnostylis Stev. in the Southern Urals: The state of natural populations and conservation issues]. Sterlitomak (in Russian).

Wolski, T., \& Baj, T. (2014). Systematyka gatunku Dictamnus oraz skład fitochemiczny dwu odmian dyptamu jesionolistnego (Dictamnus albus L. cv. albiflores i cv. rosa purple). Postępy Fitoterapii, 3, 166-179 (in Polish). 